\title{
The Effect In Changes of Persian Gulf Country Crude Oil Production, Usa Crude Oil Production, OECD Country Oil Consumption To The World Oil Price Changes
}

\author{
Wahyu Nurmanto, Mohamad Adam, Marlina Widiyanti
}

\begin{abstract}
There are background issues has generated this study, which one from the global crude oil price get reduced to around $70 \%$ in the second semester of 2014. Several observations were associated with an imbalance between the pattern of supply and demand for crude oil. This study is purposed at examining the effect of the variable crude oil production from the Gulf Country and the USA, furthermore is the variable consumption of crude oil on changes in the price of WTI crude oil (West Texas Intermediate). The secondary data has obtained by U.S. agencies. Energy Information Administration (EIA). The results processed by multiple linear regression methods in the period of observation Q3 2001 - Q4 2018, the results describe that the variables of crude oil production from Saudi countries (Persian Gulf Country) give a significant negative result ( $\beta=-4.993$; significant level 0.028$)$, and for USA Oil production variable gives a significant positive result $(\beta=0.177$; significant level 0,000) whereas OECD country consumption shows a positive result that is not significant for changes in crude oil prices ( $\beta=1,926$; significant level 0.058)

Keywords: Supply and Demand, Production, Persian Gulf Country, Consumption, WTI
\end{abstract}

\section{INTRODUCTION}

In the last 5 years, there was a phenomenon of a significant decline in world oil prices compared to previous years. This effect is directly felt by industries that conducting business in the oil and gas sector. Oil as a commodity of business results for sale will be directly related to sales and recorded as company's profit, if commodity of prices becoming reduced by on half range, so there are would makes the company's profits declined. Current situation makes the upstream business that should be the biggest supporter compared to the downstream business in an oil and gas corporation have to tightening the production and investment costs in order of company's profit income maintenace.

The demand and supply behavior can influence by many factors on a point of price formation interactions. According

Manuscript received on June 15, 2019.

Revised Manuscript received on June 25, 2019.

Manuscript published on July 30, 2019.

* Correspondence Author

Wahyu Nurmanto*, (Corresponding Author), Candidate Master of Management in Magister Management University of Sriwijaya, Indonesia.

Prof. Dr. Mohamad Adam, S.E,. M.E, Lectures in Faculty Economic University of Sriwijaya, Indonesia.

Hj. Marlina Widiyanti, S.E., S.H., M.M., Ph.D., Lectures in Faculty Economic University of Sriwijaya, Indonesia.

(c) The Authors. Published by Blue Eyes Intelligence Engineering and Sciences Publication (BEIESP). This is an open access article under the CC BY-NC-ND license (http://creativecommons.org/licenses/by-nc-nd/4.0/) information related to the quantity of crude oil traded [5], the relationship of the phenomenon of falling oil prices at the end of the first semester of 2014 is considered to be an impact of the revolution in shale oil production in the United States during the initial phase of expansion (January 2011 to mid 2014) shale oil production tripled and pushed US market share up from $7 \%$ to $12 \%$. Total US production increased $76 \%$ from nearly 5.4 million barrels per day in early 2010 to around 9.5 million barrels per day at the end of 2014. The condition was mainly due to shale oil production at the Eagle Ford and Permian locations which doubled more since 2011, while has remained stable on US conventional production.

Its support by research results of Salisu and Adediran [1], the American Shale Oil variable that compared to the total US oil supply was related to the oil prices decline. Minning commodities such as oil, coal and gas together constitute to be majority of global primary energy consumption. Between 2005 and 2030 [14], energy demand it self would projected to increase by 55 percent, with demand increasing from 11.4 billion tons of oil equivalent to 17.7 billion. During 2005 and 2030, expectation about energy consumption would increased by 50 percent, the biggest demand comes from developing countries. In the number of population growth and in he means of living standards increasing for developing countries majority people in will rissing up the energy resources demand .Irma Alonso and Di Nino [5], they found the model of SVAR, showing oil prices transition, is relevant to the shale oil production, also about $14 \%$ the oil prices changes is pushed by stronger oil demand growth $(+38 \%)$ and has balancing by an increase in supply factors (+ $10 \%)$ which contributed negatively to the oil prices dynamics. Based on the background of the problems outlined above, the research problem formulated by "The Effect In Changes Of Persian Gulf Country Crude Oil Production, USA Crude Oil Production, OECD Country Oil Consumption To The World Oil Price Changes"

\section{LITERATURE REVIEW}

\section{A. Price Theory}

The price theory basically explains about the prices formation and the allocation of flows of goods and services that construct the market flow, also assumed that shapes the market is formed by the valuation and composition of the flow of goods and services from producers to consumers. tand $\mathrm{Hu}$

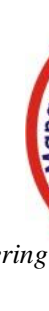


An emerging interaction by producers and consumers will determine the prices level of goods that would presented in the market and also amount of goods to be traded on the market. Interactions that occur in the market are explained through by the theory of demand and supply [12].

\section{B. Prices and Demand}

According to Sukirno [12] "The law of demand essentially states that the lower the price of an item, then the more demand would created for the item it self. Conversely, the higher the price of an item, then the less demand would created for the item ".

And then, if a small change of price would causes a large change in the amount requested, it is said that the demand for goods is very responsive to price changes or the demand is elastic. Conversely, if the price change occurs large enough but the demand does not change much, it can be said that the demand is inelastic. The coefficient of demand elasticity is calculated using the formula below :

$$
\text { Price Elasticity of Demand } \quad\left(\varepsilon_{p)}=\frac{\left(\Delta \mathrm{Q}_{\mathrm{d} /} \mathrm{Q}_{\mathrm{d})}\right.}{\left(\Delta \mathrm{P}_{/} \mathrm{P}_{)}\right.}\right.
$$

\section{Price and Supply}

According to Sukirno [12], the essence of law Supply says that the higher the price of an item, the more the amount of goods would be offered by the seller. And vice versa, the lower the price of an item, then will make less the amount of goods offered by the seller.

Then, if a small change of the price would causes a large change in the amount requested, it is said that the demand for goods is very responsive to price changes or the demand is elastic. Supply elasticity has the same properties and there are five levels of elasticity (perfectly elastic, elastic, unity elasticity, non elastic, and non perfectly elastic). The coefficient of supply elasticity can be calculated using the formula below :

Price Elasticity of Supply $\quad\left(\varepsilon_{p)} \quad=\frac{\left(\Delta \mathrm{Q}_{\mathrm{s} /} \mathrm{Q}_{\mathrm{s}}\right)}{(\Delta \mathrm{P} / \mathrm{P})}\right.$

\section{RESEARCH METHODS}

The scope of this study discusses about the relationship of changes in average value from the current period of real West Texas Intermediate (WTI) crude oil prices with supply and demand factors, consist of the the quarterly growth of volume Saudi Arabia's crude oil production which belongs to the Persian Gulf country group (Persian Gulf Country Oil Production), the production of American Oil / WTI (USA Oil Production) as well as demand factors which represented by oil consumption variables from OECD countries with a research period on third quarter years of 2001 to the fourth quarter at years of 2018. The research design between research variables from the independent variable $(\mathrm{X})$ to the dependent variable (Y) as bellow:

1. Variable $\mathrm{X}$ (Independent Variable), which is the

quarterly growth rate of Persian Gulf Country (Saudi) oil production, American oil production, and OECD country's oil consumption.

2. Variable Y (Dependent Variable), is a change (deviation to up / down) on average Crude Oil Price consumption per quarter.

\section{Data Analysis Techniques}

Regression analysis was used for this study to predict how far the change in the value of the dependent variable would be occurs if the independent variable value is set by change. The form of the equation is stated as follows:

$$
\mathrm{Y}=\alpha+\beta 1 \mathrm{X} 1+\beta 2 \mathrm{X} 2+\beta 3 \mathrm{X} 3
$$

Where :

$$
\begin{array}{ll}
\mathrm{Y} & \begin{array}{l}
\text { Quarterly Changes in Crude Oil Prices } \\
\text { (WTI Price) }
\end{array} \\
\alpha & =\text { Constans }
\end{array}
$$

$\beta 1, \beta 2, \beta 3=$ Regression line coefficient

X1 = y-o-y Change on Persian Gulf Country (Saudi) Oil Production

$\mathrm{X} 2=\mathrm{y}-\mathrm{o}-\mathrm{y}$ Change on USA Oil Production

X3 $=\mathrm{y}-\mathrm{o}-\mathrm{y}$ Change on OECD Country Oil Consumption

\section{RESUlts AND DiscussioN}

\section{General Overview and Object Description}

In this research, dependent variable is limited by 3 country group classifications which are examined the contribution of production and consumption in the third quarter 2001 period until the fourth quarter of 2018 is recorded U.S. Energy Information Administration (EIA). The average data on Changes in World Crude Oil Prices for the period 2001-2018 can be explained as follows :

Table 1. Real World Crude Oil Prices Growth for the Period of 2001-2018 (Quarterly)

\begin{tabular}{ccrrr}
\hline \multirow{2}{*}{ No } & \multirow{2}{*}{ Years } & \multicolumn{1}{c}{ Min. } & \multicolumn{1}{c}{ Max. } & \multicolumn{2}{c}{$\begin{array}{c}\text { Average } \\
\Delta \text { PWTI }\end{array}$} \\
\hline 1 & 2001 & -7.58 & -1.57 & -4.58 \\
2 & 2002 & -0.23 & 5.4 & 2.19 \\
3 & 2003 & -6.02 & 6.6 & 0.69 \\
4 & 2004 & 3.07 & 5.97 & 4.49 \\
5 & 2005 & -4.16 & 10.63 & 2.79 \\
6 & 2006 & -11.51 & 7.09 & -0.44 \\
7 & 2007 & -2.58 & 15.49 & 7.52 \\
8 & 2008 & -60.68 & 26.13 & -8.51 \\
9 & 2009 & -15.77 & 16.73 & 4.31 \\
10 & 2010 & -2.03 & 8.68 & 1.99 \\
11 & 2011 & -12.78 & 8.31 & 1.75 \\
12 & 2012 & -9.71 & 8.01 & -1.92 \\
13 & 2013 & -8.36 & 10.62 & 1.85 \\
14 & 2014 & -22.84 & 3.77 & -5.96 \\
15 & 2015 & -22.79 & 8.33 & -7.30 \\
16 & 2016 & -7.84 & 10.81 & 1.49 \\
17 & 2017 & -3.25 & 6.02 & 1.13 \\
18 & 2018 & -8.98 & 6.47 & 0.68 \\
\hline
\end{tabular}

Source : Data processing results, 2019 
Beside that, the independent variable consists of Crude Oil Production year-on-year from Persian Gulf Country (Saudi), USA Crude Oil Production and the rate of change in OECD country Crude Oil Consumption on the period of 2001-2018 can be seen bellow:

Table 2. Changes in Oil Production Persian Gulf Country (Saudi), U.S.A, and OECD Countries Crude Oil

Consumption Growth Rate Period of 2001-2018

\begin{tabular}{rrrrr}
\hline No & Years & $\begin{array}{c}\text { change of } \\
\text { Prod. } \\
\text { GC/Saudi } \\
\text { (volume) }\end{array}$ & $\begin{array}{c}\text { change of } \\
\text { Prod. } \\
\text { USA/WTI } \\
\text { (volume) }\end{array}$ & $\begin{array}{c}\text { cons. OECD } \\
\text { change of }\end{array}$ \\
\hline 1 & 2001 & -0.935 & -25.825 & -0.775 \\
2 & 2002 & -0.4 & 3.3425 & -0.05 \\
3 & 2003 & 1.145 & 21.185 & 1.4625 \\
4 & 2004 & 0.3225 & 33.86 & 1.6675 \\
5 & 2005 & 0.45 & 37.2175 & 0.715 \\
6 & 2006 & -0.3975 & 17.715 & -0.3475 \\
7 & 2007 & -0.435 & 10.435 & -0.1975 \\
8 & 2008 & 0.5375 & 45.2625 & -3.4825 \\
9 & 2009 & -1.0425 & -30.1725 & -4.08 \\
10 & 2010 & 0.64 & 34.2775 & 1.2775 \\
11 & 2011 & 0.56 & 19.63 & -1.14 \\
12 & 2012 & 0.3775 & -0.65 & -0.8975 \\
13 & 2013 & -0.1425 & 4.5125 & 0.1725 \\
14 & 2014 & 0.045 & -4.4825 & -0.605 \\
15 & 2015 & 0.4325 & -47.51 & 1.6375 \\
16 & 2016 & 0.295 & -9.755 & 0.9575 \\
17 & 2017 & -0.3275 & 20.12 & 0.9575 \\
18 & 2018 & 0.29 & 28.93 & 0.55 \\
\hline
\end{tabular}

Source : Data processing results, 2019

Table 3. Descriptive Statistical test Results

\begin{tabular}{lcrrrr}
\hline & N & \multicolumn{1}{c}{ Min. } & Max. & Mean & Std. Dev. \\
\hline PPWTI & 70 & -60.68 & 26.13 & 0.256 & 11.142 \\
Prod.GC & 70 & -1.19 & 1.69 & 0.108 & 0.656 \\
Prod.USA & 70 & -55.91 & 90.52 & 9.772 & 32.419 \\
C.OECD & 70 & -5.74 & 3.38 & -0.10 & 1.842 \\
Valid N & 70 & & & & \\
(listwise) & & & & & \\
\hline
\end{tabular}

Source : Data processing results, 2019

Refer to data processing results, each average variable value compared to the standard deviation shows a greater value . that interpreted sample has a good data distribution.

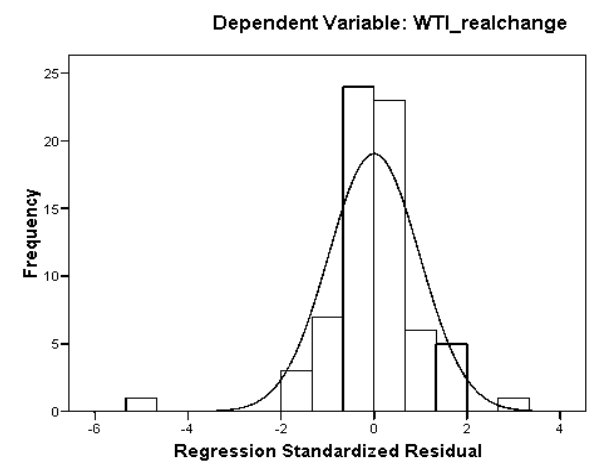

Figure 1. Normality Test Graph Analysis Results Source : Data processing results, 2019
Table 4. Kolmogorov-Smirnov Normality Test

Unstand. Residual

\begin{tabular}{llr} 
N Normal Parameters & $\begin{array}{l}\text { Mean } \\
\text { Std. }\end{array}$ & 70 \\
& $\begin{array}{l}\text { Deviation } \\
\text { Most Extreme }\end{array}$ & 9.64012758 \\
Difference & Absolute & .116 \\
& Positive & .097 \\
Kolmogrov-Smirnov Z & Negative & -.116 \\
Asymp. Sig. (2-tailed) & & 0.969 \\
& & .741 \\
\hline Source ·Data processing results, 2019
\end{tabular}

According to table 4, as generated value at 0.741 (greater than 0.05 ). shows the results for this case above 0.05 also can be interpreted which the residual data are normally distributed.

Table 5. Multicollinearity test results

\begin{tabular}{lcccc}
\hline Variable & \multirow{2}{*}{ VIF } & & $\begin{array}{c}\text { Cutt } \\
\text { Off }\end{array}$ & Conclusion \\
& & & & \\
\hline Prod.GC & 1.504 & $<$ & 10 & No Multicollinearity \\
Prod.USA & 1.251 & $<$ & 10 & No Multicollinearity \\
C.OECD & 1.241 & $<$ & 10 & No Multicollinearity \\
\hline
\end{tabular}

Source :Data processing results, 2019

Table 6. Autocorrelation test results

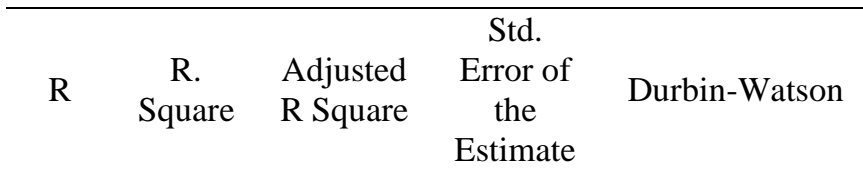

\begin{tabular}{lllll}
\hline .501 & .251 & .217 & 9.85679 & 1.708 \\
\hline
\end{tabular}

Source :Data processing results, 2019

Obtained value of Durbin Watson (DW) about 1.708. based on the DW-table: $\mathrm{dL}$ (outer limit/durbin lower) = 1,525; du (inner limit/durbin upper) = 1,703; 4-dL = 2,683; and 4-du $=2,480$. Thus, it can be concluded that the DW-test has been located is measure non-autocorrelation variables.

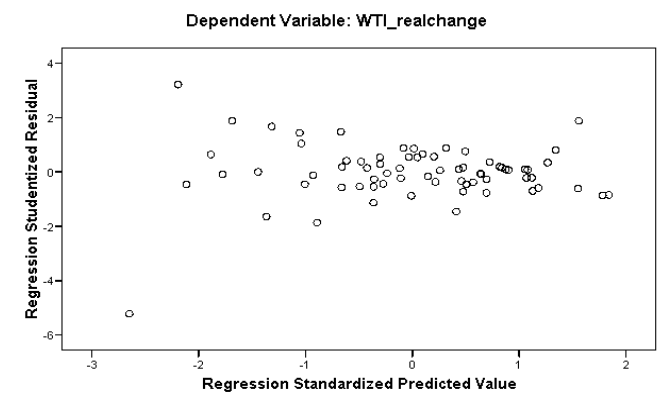

Figure 2. Heteroscedasticity Test Results Source : Data processing results, 2019 
Fig. 2 measure accepted if points was spreaded above and below from zero value.

\section{Feasibility Model Test (F Test)}

The $\mathrm{F}$ statistical test basically shows whether all the independent variables has been included in the model did have a simultaneously effects on the dependent variable. decision making criteria for the tests is as follows:

- Does not have a significant effect if the probability level of F (Sig F)> 0.05

- Has a significant effect if the probability level of $F$ $($ Sig F $)<0.05$

Table 7. Output ANOVA

\begin{tabular}{lrrrcc}
\hline & $\begin{array}{c}\text { Sum } \\
\text { of } \\
\text { Squares }\end{array}$ & \multicolumn{1}{c}{ Df } & $\begin{array}{c}\text { Mean } \\
\text { Square }\end{array}$ & F & Sig. \\
\hline Regression & 2153.4 & 2 & 717.813 & 7.388 & 0.000 \\
Residual & 6412.3 & 66 & 97.156 & & \\
Total & 8565.8 & 69 & & & \\
\hline
\end{tabular}

Source : Data processing results, 2019

\section{Partial Test (t test )}

Purposed to find out the coefficient of regression partially (individually), the objective is to determine the partial significance each of independent variables to the dependent variable by assuming the other independent variables are considered constant positions

Table 8. Output ANOVA

\begin{tabular}{lrrrrr}
\hline \multicolumn{7}{c}{ Unstandardized } \\
Coefficients & \multicolumn{1}{c}{$\begin{array}{l}\text { Stand } \\
\text { Std. }\end{array}$} & $\begin{array}{l}\text {.Coef. } \\
\text { Beta }\end{array}$ & & \\
& \multicolumn{1}{c}{ B } & Eror & T & Sig. \\
\hline Constant & -.800 & 1.242 & & -.644 & .522 \\
Prod.GC & -4.993 & 2.219 & .294 & -2.250 & .028 \\
Prod.USA & .177 & .041 & -.516 & 4.334 & .000 \\
C.OECD & 1.383 & .718 & .229 & .926 & .058
\end{tabular}

Dependent variable: Changes in World Crude Oil Prices $(\triangle \mathrm{PWTI})$

Source : Data processing results, 2019

\section{Coefficient of determination Test}

When the value (R2) has close to one (100\%) it can be translated that the independent variables provide most of information in the research purposes to predict variations in the dependent variable. The calculation of the determination coefficient (R2) can be seen in the table below:

\section{Table 9. Coefficient of Determination}

\begin{tabular}{ccccc}
\hline R & $\begin{array}{c}\text { R. } \\
\text { Square }\end{array}$ & $\begin{array}{c}\text { Adjusted } \\
\text { R Square }\end{array}$ & $\begin{array}{c}\text { Std. } \\
\text { Error of } \\
\text { the } \\
\text { Estimate }\end{array}$ & Durbin-Watson \\
\hline .501 & .251 & .217 & 9.85679 & 1.708 \\
\hline
\end{tabular}

Source : Data processing results, 2019

The calculation shows about the measure of dependent variable effect on the independent variables can be descript by this equation model is $25.1 \%$ which the remaining $74.9 \%$ is influenced by other factors was not included for this regression transformation model, such as macro, sentiment of market factors and state political factors.

\section{Multiple Linear Regression Analysis}

Based on the results of calculations from table 8, the equation obtained as shows bellow:

$$
Y=-0.800-4.993 X_{1}+0.177 X_{2}+1.383 X_{3}
$$

And describe as :

1. The $t$ test results value of $\mathrm{X} 1$ variable is $-2.250>$ -1.99656 ( $\mathrm{t}$ of table), and the significance output shows $0.028<0.05$, which means the variable Prod. GC has a negative and significant affect on $\triangle \mathrm{PWTI}$.

2. The t test results value of $\mathrm{X} 2$ variable is $4.334>1.99656$ ( $\mathrm{t}$ of table), and the significance output shows 0.000 $<0.05$ which means the Prod variable. USA has a positive and significant affect on $\triangle \mathrm{PWTI}$.

3. The $t$ test results value of $\mathrm{X} 3$ variable is $1.383<1.99656$ ( $\mathrm{t}$ of table), and the significance output shows 0.058 $>0.05$ do not affect as partially for $\Delta$ PWTI.

\section{DISCUSSION}

The research obtained, in the quarterly observation period of 2001 to 4th quarter in 2018 the variables of Saudi Crude Oil Production which are members of OPEC and the Persian Gulf Country (Prod. GC) have a negative and significant result on Changes in World Crude Oil Prices (WPWTI). Accordance with the price theory, where the quantity and price of the product has a tendency to be influenced by the supply / demand factor for the product itself. In the crude oil industry, the supply-demand curve pattern tends to inelastic characters form. So that made the causes of world oil price volatility. The movement of the supply curve due to changes in endogen and exogenous factors from oil producers will have a significant effect on world crude oil prices. While the stagnant demand curve consequence. the other results, the variables of USA Oil Production give a negative result and are significant to changes. Give a positive and significant value. This is not in line with the price theory mentioned. However, this can be related to the strategy, and macroeconomic and political conditions that take place in oil-non producing countries members (Non OPEC). These findings support the results of research from Caldara [2]; Marco [10]; Takuji [11]; Ibrahim [4]; Killian [8] which states that crude oil production will affect to the changes in world crude oil prices.

Furthermore, OECD country crude oil consumption (C.OECD) gives a positive and insignificant result. This is in accordance with the price theory, with the demand character for fossil energy that have a growing trend, the change in the pattern of the demand curve in inelastic curve will drive positive for oil prices. 


\section{CONCLUSION AND RECOMMENDATIONS}

\section{Conclusion}

Based on the analysis and discussion in the previous chapter, it can be concluded that the results of this study are as follows:

1. Any changes that occur to the independent variables that Persian Gulf Country Production (Prod.GC), USA Crude Oil Production (Prod. USA), and OECD countries (C.OECD) Crude Oil Consumption simultaneously has an effect on Changes in World Crude Oil Prices ( $\triangle \mathrm{PWTI})$.

2. Persian Gulf Country Crude Oil Production (Prod.GC) Variables has a negative and significant effect on the variable Changes in World Crude Oil Prices ( $\triangle \mathrm{PWTI})$ during the observation period 2001-2018 where the $\beta$ coefficients obtained from the calculation are -4.993 with a significance level less than 0.05 (0.028).

3. USA Crude Oil Production (Prod. USA) Variables have a positive and significant effect on the variable Changes in World Crude Oil Prices ( $\triangle \mathrm{PWTI}$ ) in 2001-2018 where the coefficient of $\beta$ obtained from the calculation is 0.177 with a significant level less than $0.05(0,000)$

4. OECD Consumption of Crude Oil (C. OECD) Variables has a positive and not significant effect on the variable Changes in World Crude Oil Prices ( $\triangle \mathrm{PWTI}$ ) during observation period 2001-2018 where the coefficient of $\beta$ obtained from the calculation is 1,383 with a significant level greater than 0.05 (0.058)

5. The independent variable that has a significant and dominant influence is the variable USA Crude Oil Production (Prod. USA) and shows a negative and significant effect results on Changes in World Crude Oil Prices ( $\Delta$ PWTI) in 2001-2018

\section{Recommendations}

Based on the results of research, discussion, and conclusions that have been described previously, the author can submit several suggestions in this study as follows:

1. Companies that are engaged in upstream oil and gas business, especially those that are part of SOEs, are expected to make the phenomenon of the decline in world oil prices that significantly occurred in second quartile of 2014 as a lesson learned, both from the signal of the crude oil prices weakness period (consider factors in this study that has significantly affects) also internally handling procedure if in real terms world oil prices was significantly fall.

2. The next researcher is expected to be able examine other variables outside of this variable in order to obtain more varied results that can provide an overview of matters that can affect changes in World Crude Oil Prices (WPWTI) and can extend the observation period and are advised to expand the scope of the study this is like the influence of other commodities (substitute goods), macroeconomic factors, and other factors that influence the price of a commodity.

\section{REFERENCES}

1. Afees A. Salisu, Idris A. Adediran. 2018. US Shale Oil and The Behaviour of Commodity Prices. Centre for Econometric and Allied Research, University of Ibadan Working Papers Series, CWPS 0047.
2. Caldara, Michelle, Matteo. 2016. Oil Price Elasticities and Oil Price Fluctuations. International Finance Discussion Papers.

3. Ghozali, Imam. 2013. Aplikasi Multivariate dengan Program SPSS Edisi Ketujuh. Semarang: Badan Penerbit Universitas Diponegoro.

4. Ibrahim, Mas'ud. 2014. Towards Realisation of Stable Oil Prices: An Empirical Analysis of the Impact of OPEC's Oil Price Band/ Stabilisation Policies. Robert Gordon University Aberdeen.

5. Irma A., Virginia De Nino. 2017. The Oil Market in The Age of Shale Oil. ECB Economic Bulletin, Issue 8/2017.

6. Latan, Hengky dan Selva Temalagi. 2013. Analisis Multivariate Teknik dan Aplikasi Menggunakan Program IBM SPSS 20.0. Bandung: Penerbit Alfabeta.

7. Lubiantara, Benny. 2012. Ekonomi Migas (Tinjauan Aspek Komersial Migas).

8. Lutz, Kilian. 2008. Not All Oil Price Shocks Are Alike: Disentangling Demand and Supply Shocks in The Crude Oil Market. University of Michingan and CEPR.

9. Mankiw, N. Gregory. 2003. Macroeconomics, 5th Edition. New York: Worth Publishers.

10. Marco, Laruso Luca. 2015. Cause and Consequences of Oil Price Shocks on The UK Economy. Heriot-Watt University Edinburg.

11. Takuji, Hiroka. 2018. Indentifying Oil Price Shocks and Their Consequences: The Role of Expectations in The Crude Oil Market. Bank for International Settlements.

12. Sukirno, Sadono. 2011. Mikro Ekonomi, Edisi 3. Jakarta: PT RajaGrafindo Persada

13. U.S. Energy Information Administration accessed on February 2019.

14. https://www.bbc.com/bitesize/guides/zpmmmp3/revision/1 accessed on February 2019.

\section{AUTHORS PROFILE}

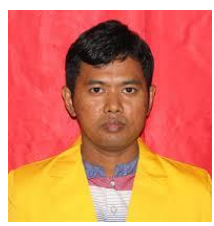

Wahyu Nurmanto, Corresponding Author, Candidate Master of Management in Magister Management University of Sriwijaya, Indonesia.

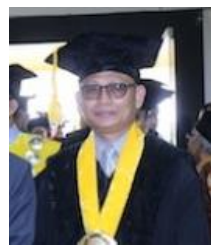

Prof. Dr. Mohamad Adam, S.E,. M.E, Lectures in Faculty Economic University of Sriwijaya, Indonesia.

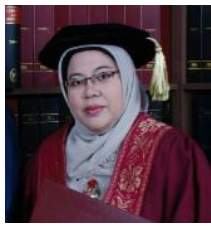

Hj. Marlina Widiyanti, S.E., S.H., M.M., Ph.D., Lectures in Faculty Economic University of Sriwijaya, Indonesia. 